\title{
ESTIMATION OF EVAPOTRANSPIRATION FOR BASILICATA REGION WITH A PENNMAN-MONTEITH METHOD
}

\section{Hamidreza Khanjanzadeh ${ }^{1,2, *}$, Enrico C. Borgogno Mondino ${ }^{2}$ and Elham Morteza ${ }^{3}$}

\author{
${ }^{1}$ Iran-Italy Chamber of Commerce, Tehran, Iran \\ ${ }^{2}$ Department of Agriculture, Foresty and Food Science, University of Turin, Turin, Italy \\ ${ }^{3}$ Young Researchers and Elite Club, Shahr-e-Qods Branch, Islamic Azad University, Tehran, Iran
}

Received - January 27, 2017; Revision - March 25, 2017; Accepted - April 24, 2017

Available Online - May 12, 2017

DOI: http://dx.doi.org/10.18006/2017.5(2).183.187

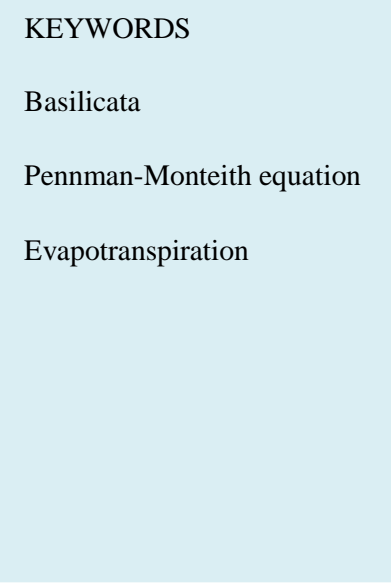

\begin{abstract}
Estimation of reference evapotranspiration rate is a very significant parameter in agriculture science. It indicates the water consumption of the plant. So, it plays an important role in irrigation scheduling as well as plant growth modeling. In most cases, reference evapotranspiration has been computed by the Penman-Monteith equation (PM) as recommended by the FAO and applied over different climates over the globe. Information on $\mathrm{ET}_{\mathrm{c}}$ and crop coefficients $(\mathrm{Kc})$ is useful for normal irrigation planning and management purposes, for the development of basic irrigation schedules, and for most hydrologic water balance studies. Therefore, according to the importance of $\mathrm{ET}_{\mathrm{c}}$ for agriculture planning and management purposes, this study was conducted in order to estimate the rate of evapotranspiration with a PennmanMonteith method for Basilicata region. The results of this experiment showed that, $\mathrm{ET}_{\mathrm{c}}$ calculated with Penman equation for arable land was $3.90(\mathrm{~mm} / \mathrm{d})$ while it was reported $2.95(\mathrm{~mm} / \mathrm{d})$ for Vineyard area and $3.07(\mathrm{~mm} / \mathrm{d})$ for Pasture polfit. Result of study revealed that sample areas which were close to the lake Pertusillo, rates of ET on average higher than other areas.
\end{abstract}

* Corresponding author

E-mail: hamidrezakhanjanzadeh2017@yahoo.com (Hamidreza Khanjanzadeh)

Peer review under responsibility of Journal of Experimental Biology and Agricultural Sciences.

Production and Hosting by Horizon Publisher India [HPI] (http://www.horizonpublisherindia.in/).

All rights reserved.
All the article published by Journal of Experimental Biology and Agricultural Sciences is licensed under a Creative Commons Attribution-NonCommercial 4.0 International License Based on a work at www.jebas.org.

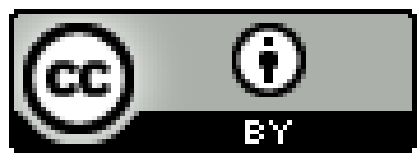




\section{Introduction}

Evapotranspiration is the largest hydrological flux in the summer months under plains. The ability of estimating the magnitude of this flux will, therefore, go a long way toward computing the water balance and planning the use of available water resources (Peacock \& Hess, 2004). It is, however, the most difficult flux to quantify (Peacock \& Hess, 2004). Evapotranspiration (ET) is a fundamental component of the water cycle and profoundly important for the energy cycle. An understanding of ET is crucial for myriad scientific and management issues, including hydrology (Buytaert et al., 2006; Senay et al., 2009), hydroinformatics (Vázquez \& Hampel, 2014), water resources management (Kisi \& Cengiz, 2013), agricultural management (Yoder et al., 2005a), crop simulation models (Ababaei, 2014), climatology (Midgley et al., 2002), ecohydrology (D’Odorico et al., 2010), and even biodiversity (Fisher et al., 2011; Córdova et al., 2015). Evapotranspiration process is the combination of two separate processes commonly known as Evaporation and Transpiration. In this process water is lost on the one hand from the top soil or water surface by evaporation and on the other hand from the crop plant tissues through transpiration by stomatal dynamics (Allen et al., 1996). Estimates of evapotranspiration provide an outlook of soil water balance in association with the amount of precipitation. Such estimates are of immense importance for calculation of water demand of the field crops and irrigation scheduling (Rasul, 1992). It also determines the nature of agro-climate a region has, agroclimatic potential of that region and suitability of crops or varieties, which can be grown successfully with the best economic returns (Mashru \& Dwived, 2016)

A reference evapotranspiration rate is a very significant parameter in agriculture science. It indicates the water consumption of the plant. So, it plays an important role in irrigation scheduling as well as plant growth modeling (Yoder et al., 2005b). In most cases, reference evapotranspiration has been computed by the PenmanMonteith equation (PM) as recommended by the FAO and applied over different climates over the globe (Penman, 1948; Allen et al.,
1998, Garcia et al., 2004). Crop production, however, demands not only efficient use of nutrients but also efficient and economic utilization of water, especially when it is applied artificially. Crop evapotranspiration $\left(\mathrm{ET}_{\mathrm{c}}\right)$ is a principal factor of crop productivity in humid and sub-humid tropics. In these regions, when soil water is available, $\mathrm{ET}_{\mathrm{c}}$ can reach or even exceed $10 \mathrm{~mm}^{\text {day }}{ }^{-1}$ under low atmospheric humidity and high wind velocity conditions (Fasinmirin \& Olufayo, 2009). Information on $\mathrm{ET}_{\mathrm{c}}$ and crop coefficients $(\mathrm{Kc})$ is useful for normal irrigation planning and management purposes, for the development of basic irrigation schedules, and for most hydrologic water balance studies (Tyagi et al., 2000; Suleiman et al., 2007). The objective of this study, therefore, is estimation of evapotranspiration for Basilicata region with a Pennman-Monteith method.

\section{Materials and Methods}

This study was conducted in Basilicata region of Italy; this is the most mountainous region of the south of Italy (Figure 1). The region is divided in to two provinces, Potenza and Matera. The territory of the region Basilicata is characterized by an extensive river network, where some of the bigger waterways are Bradano, the Cavone, the Agri and the Sinni. Mountain area is represented by $8.356 \mathrm{~km}^{2}$ while, for the remaining parts, $45 \%$ is hilly, and $8 \%$ is made up of plains. The test area is a part of the Agri Valley. The Agri Valley is a sub region of Basilicata in the south of Italy between the mountains and Sirino Volturino. This area covers $1,417.53 \mathrm{KM}^{2}$ and it also has 52.422 inhabitants; its altitude ranges from 0 to $1.559 \mathrm{~m}$ a.s.l., then an average altitude of 746 meters a.s.l.

During study following regions based on the land cover were studied: Hedges, Pasture, Small Ponds, Orchard, Vineyard and Arable area. The territory of the Agri Valley is also rich in forests. From vegetation point of view, the strip with the lower altitude has evergreen oak and thermophilic woods with oak, hornbeam, and flowering ash. In the higher strips there is widespread beech woods mixed with oaks and holly, white pine, lobelia or maple.

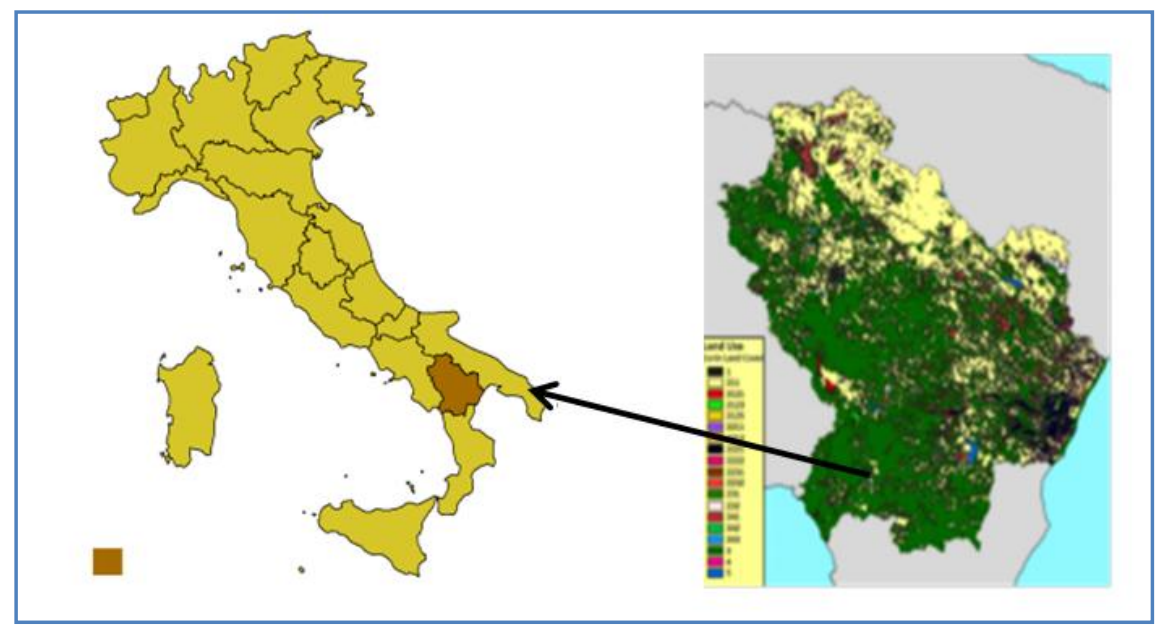

Figure 1 Italy, and Basilicata region showed in dark green

Journal of Experimental Biology and Agricultural Sciences

http://www.jebas.org 


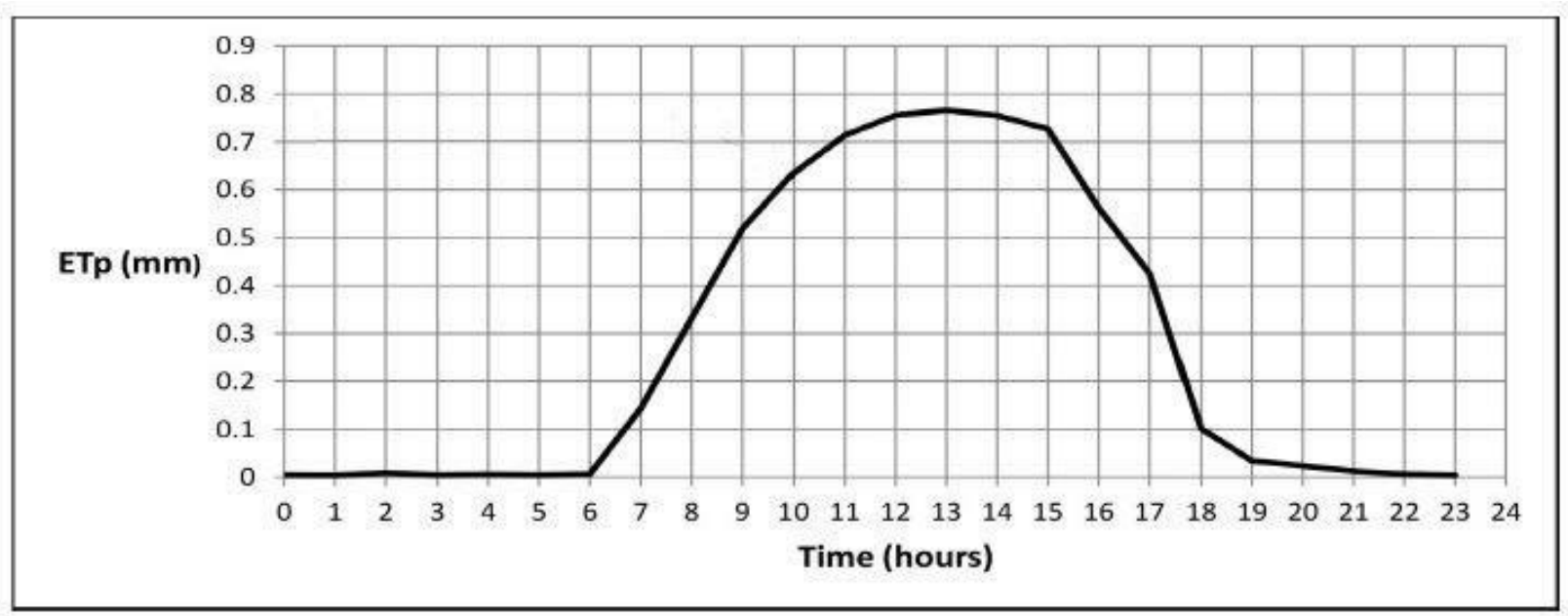

Figure 2 Daily $\mathrm{ET}_{\mathrm{p}}(\mathrm{mm} /$ day) of Agri Valley area

The remaining fire wood of Laurenzana is one of the most important forests of its kind in southern Europe. Due to the heterogeneity of the test area three discrete vegetation regions viz arables, vineyards and pastures and deciduous forest were selected based on the land cover.

The Pennman-Monteith equation is the standard FAO method to determine reference crop water ET (ETp) (Allen et al., 1998) and makes use of meteorological data. The estimation of ET was based on the FAO Penman-Monteith methodology which was calculated as:

$\mathrm{ET}_{\mathrm{C}}=\mathrm{ET}_{\mathrm{P}} \times \cdot \mathrm{K}_{\mathrm{C}}$

Where $\mathrm{ET}_{\mathrm{C}}$ is the crop ET under standard condition, it will be between 1 to $9 \mathrm{~mm} / \mathrm{day}$ from cool to warm average temperature and ETp is the potential evapotranspiration and $\mathrm{K}_{\mathrm{C}}$ is the coefficient factor for a well watered crop in optimal agronomic condition. Figure 2 shows ETp as the result of the PenmanMonteith equation based on Villa d'Agri meteorological station data. ET $_{\mathrm{P}}$ calculated using the Pennman-Monteith equation in this figure was based on the weather data retrieved from the Agenzia Regionale per la Protezione dell'Ambiente (ARPA) Basilicata's meteorological station of Villa d'Agri, the nearest to the test area.

\section{Results and Discussion}

Determination of the actual crop evapotranspiration $\left(\mathrm{ET}_{\mathrm{c}}\right)$ during the growing period is important for accurate irrigation scheduling in arid and semi-arid regions. Development of a crop coefficient $\left(\mathrm{K}_{\mathrm{c}}\right)$ can enhance $\mathrm{ET}_{\mathrm{c}}$ estimations with relation to specific crop phenological development (Kenjabaev et al., 2014). Results of this experiment showed that, value of $\mathrm{ET}_{\mathrm{c}}$ calculated with Penman equation for arable land was $3.90(\mathrm{~mm} / \mathrm{d})$, while this was 2.95 $(\mathrm{mm} / \mathrm{d})$ for Vineyard area and $3.07(\mathrm{~mm} / \mathrm{d})$ for Pasture polfit (Table 1).

Results of study suggested that sample areas which were close to the lake Pertusillo, rates of ET on average higher than other areas. This is due to the higher water content in the soils surrounding the lake and consequently the greater availability of water for ET.

Eastimation of Etc is an important parameter for the estimation of water requirement and in this calculation is the distance from the lake (Chanthai \& Wonprasaid, 2016). In Table 1 crop ET (ET $\left.{ }_{C}\right)$ estimated by the Penman-Monteith. It has been chosen Kc for the arable area in the Basilicata of $(0.60)$. Kc is the crop coefficient which is affected by several factors such as crop types, crop stages and cultural practices.

Table 1 Values of $\mathrm{ET}_{\mathrm{C}}(\mathrm{mm} / \mathrm{d})$ for arable, vineyard pasture of test area

\begin{tabular}{|lccc|}
\hline Area & $\mathbf{E T}_{\mathbf{p}}(\mathbf{m m} / \mathbf{d})$ & $\mathbf{K}_{\mathbf{c}}$ & $\mathbf{E T}_{\mathbf{c}}(\mathbf{m m} / \mathbf{d})$ \\
\hline Arable area near the lake & 6.55 & 0.60 & 3.90 \\
\hline Arable area far from the lake & 6.55 & 0.60 & 3.90 \\
\hline Arable area average distance the lake & 6.55 & 0.60 & 3.90 \\
\hline Vineyard area near the lake & 6.55 & 0.45 & 2.95 \\
\hline Vineyard area far from the lake & 6.55 & 0.45 & 2.95 \\
\hline Pasture polfit far from the lake & 6.55 & 0.47 & 3.07 \\
\hline
\end{tabular}


The Kc coefficient is different in the vineyard (0.45) and pasture (0.47). Results of Milella \& Dettori (1987) and Dettori (1987) also determined the crop water requirements in a young orchard of Oli mana olive plants in Sardibia, concluding that the optimum Kc was 0.5 from May to September and 0.55 in April and October.

\section{Conflict of interest}

Authors would hereby like to declare that there is no conflict of interests that could possibly arise.

\section{References}

Ababaei B (2014) Are weather generators robust tools to study daily reference evapotranspiration and irrigation requirement? Water Resources Management 28: 915-932. DOI: 10.1007/s11269-014-0524-3.

Allen RG, Pereira LS, Raes D, Smith M (1998) Crop evapotranspiration-Guidelines for computing crop water requirements-FAO Irrigation and drainage paper 56. FAO Rome. 300: 6541.

Allen RG, Pruitt WO, Businger JA, Fritchen LJ, Jensen ME, Quetta FH (1996) Chapter "Evaporation and Transpiration" in a ASCE Handbook of HYDROLOGY. New York, NY=. P. $125-252$

Buytaert W, In iguez V, Ce'lleri R, Bie`vre B De, Wyseure G, Deckers J (2006) Analysis of the water balance of small pa'ramo catchments in south Ecuador. In: Krecek J, Haigh M (Eds.) Environmental Role of Wetlands in Headwaters. NATO Science Series IV: Earth and Environmental Series 63. Dordrecht, the Netherlands: Springer pp 271-281.

Chanthai S, Wonprasaid S (2016) Effects of fertigation and water application frequency on yield, water and fertilizer use efficiency of chili (Capsicum annuum L.). International Journal of Research in Chemical, Metallurgical and Civil Engineering 3: 209-213.

Córdova M, Carrillo-Rojas G, Crespo P, Wilcox B, Célleri R (2015) Evaluation of the penman-monteith (FAO 56 PM) method for calculating reference evapotranspiration using limited data. Mountain Research and Development 35: 230239. http://dx.doi.org/10.1659/MRD-JOURNAL-D-14-0024.1.

D’Odorico P, Laio F, Porporato A, Ridolfi L, Rinaldo A, Rodriguez-Iturbe I (2010) Ecohydrology of terrestrial ecosystems. BioScience 60: 898-907. DOI: https://doi.org/10. 1525/bio. 2010. 60. 11.6.

Dettori S (1987) Estimacion con los metodos de la FAO de las necesidades de riego de los cultivos de aceitunas de mesa de Cerde na. Olivae 17: 30-35.
Fasinmirin JT, Olufayo AA (2009) Yield and water use efficiency of jute mallow Corchorus olitorius under varying soil water management strategies. Journal of Medicinal Plants Research 3: 186-191.

Fisher JB, Whittaker RJ, Malhi Y ET (2011) come home: Potential evapotranspiration in geographical ecology. Global Ecology and Biogeography 20: 1-18.

Garcia M, Raes D, Allen R, Herbas C (2004) Dynamics of reference evapotranspiration in the Bolivian highlands (Altiplano). Agricultural and Forest Meteorologyis 165: 67-82. DOI: 10.1016/j.agrformet.2004.03.005.

Kenjabaev S, Dernedde Y, Frede H-G, Stulina G (2014) Determination of actual crop evapotranspiration (ETc) and dual crop coefficients $(\mathrm{Kc})$ for cotton, wheat and maize in Fergana Valley: integration of the FAO-56 approach and BUDGET. Geophysical Research Abstracts. 16, EGU-405-1.

Kisi O, Cengiz TM (2013) Fuzzy genetic approach for estimating reference evapotranspiration of Turkey: Mediterranean region. Water Resources Management 27: 3541-3553. DOI: 10.1007/s11269-013-0363-7.

Mashru HH, Dwived DK (2016) Evaluation of evapotranspiration estimation models for junagadh city of Gujarat. Current World Environment 11: 619-630. DOI : http://dx.doi.org/10.12944/CWE.11.2.34.

Midgley GF, Hannah L, Millar D, Rutherford MC, Powrie LW (2002) Assessing the vulnerability of species richness to anthropogenic climate change in a biodiversity hotspot. Global Ecology and Biogeography 11: 445-451. DOI: 10.1046/j.1466822X.2002.00307.x.

Milella A, Dettori S (1987) Regimes water optimal and partial to young trees from the table. Frutticoltura 8: 65-69.

Peacock CE, Hess TM (2004) Estimating evapotranspiration from a reed bed using the Bowen ratio energy balance method. Hydrological Processes 18: 247-60. DOI: 10.1002/hyp.1373.

Penman HL (1948) Natural evaporation from open water, bare soil, and grass. Proceedings of the Royal Society of London. Proceeding of the Royal Society Series A, Mathematical and Physical Sciences 193: 116-140. DOI: $10.1098 /$ rspa.1948.0037.

Rasul G (1992) Water Requirement of Wheat Crop in Pakistan. Journal of Engineering and Applied Sciences 3: 65-79.

Senay GB, Asante K, Artan G (2009) Water balance dynamics in the Nile Basin. Hydrological Processes 3681: 3675-3681. DOI: 10.1002/hyp.7364. 
Suleiman AA, Tojo Soler CM, Hoogenboom G (2007) Evaluation of FAO-56 crop coefficient procedures for deficit irrigation management of cotton in a humid climate. Agricultural Water Management 91: 33-42. DOI: 10.1016/j.agwat.2007.03.006.

Tyagi NK, Sharma DK, Luthra SK (2000) Determination of evapotranspiration and crop coefficients of rice and sunflower with lysimeter. Agricultural Water Management 45: 41-54. DOI: 10.1016/S0378-3774(99)00071-2.

Va'zquez RF, Hampel H (2014) Prediction limits of a catchment hydrological model using different estimates of
ETp. Journal of Hydrology 513: 216-228. DOI: 10.1016/j.jhydrol.2014.03.051.

Yoder RE, Odhiambo LO, Wright WC (2005a) Evaluation of methods for estimating daily reference crop evapotranspiration at a site in the humid southeast United States. Applied Engineering in Agriculture 21: 197-202. http://digitalcommons.unl.edu/biosysengfacpub/450.

Yoder RE, Odhiambo LO, Wright WC (2005b) Evalution of methods for estimating daily reference crop evaporanspiration at a site in the humid southeast United States. Applied Engineering in Agriculture 197-202. http://digitalcommons.unl.edu/biosysengfacpub/450. 